\title{
Effects of chitosan concentration on the quality and storage time of poultry eggs
}

\author{
Nguyen Minh Tri*, Che Thi Cam Ha, Vo Van Quy, Nguyen Bao Hai, Tran Thi Hao \\ University of Sciences, Hue University, Thua Thien Hue, Vietnam
}

(Received: 25/10/2020; Accepted: 08/12/2020)

\section{Abstract}

This paper presents some results associated with physicochemical changes of fresh duck eggs after being preserved by chitosan membranes at different concentrations. Chitosan coating at the concentration of $1.5 \%$ worked best for preserving fresh duck eggs at normal temperature. The number of total Coliforms after 30 days was 30 Coliforms/100 g sample. There was no detection of the existence of Salmonella in eggs of experimental samples.

Keywords: Fresh duck eggs, chitosan membrane, quality, storage.

\section{INTRODUCTION}

Duck eggs are a nutrient-rich food, becoming more popular in daily meals. In our country, due to the hot and humid climate, poultry eggs are easy to be rotten. This is because of the process of gas and water exchange as well as bacteria contamination through the stomata on the surface of the eggshells, causing loss of egg weight and changes of components inside the eggs, especially the growth of microorganisms that made eggs spoiled. Therefore, many scholars are interested in using membranes coated on eggs to the use of membranes on the surface of the eggshells which aims to inhibit gas exchange and anti-infection and to prolong storage time.

Currently, chitosan has been widely studied and applied in many fields of life. Due to the ability to creating membranes, limiting dehydration, antibacterial, antifungal of chitosan, this application can be used in food preservation $[4,7]$.

This paper presents some results of physicochemical changes of fresh duck eggs after being preserved by chitosan membranes at different concentrations.

\section{MATERIALS AND METHODS}

\subsection{Research subjects}

- Chitosan flake, ivory, deacetyl degree of $94 \%$ are made from white leg shrimp shells at Biology Department - College of Sciences, Hue University.

- Fresh duck eggs were purchased at farms in Huong Tra district, Thua Thien Hue province. Eggs samples were taken from the same farm, uniform in size, color, free of external defects, and weighed from 60 - $65 \mathrm{~g}$.

\subsection{Research Methods}

- Chitosan was first dissolved in $1 \%$ acetic acid at the concentration of $0.5-2.0 \%$. Next, the solution was stabilized for 10 hours. It was then filtered. A filtered solution was finally 
used to create the membrane [8]. Each experimental formula was conducted with 30 eggs initially assessed as free from microbiological contamination.

- After being selected with even sizes and making cleaned, the fresh duck eggs were put into the previously prepared chitosan solution for 15 seconds, and then they were taken out, to dry naturally. After the eggshells were dried, the eggs were immersed for the second time in the solution at a similar time. Finally, the eggs were preserved at a temperature between $25-30^{\circ} \mathrm{C}[9]$.

- Determine egg weight loss by using the weighing method [4]

- Determine the contents of protein in the egg by using the Biure method [3]

- Determine the contents of $\mathrm{NH}_{3}$ in the egg by using the distillation and titration method [3]

- Identify the total Coliforms by using the MPN method [5]

- Identify Salmonella according to Vietnam Standard (TCVN) 10780-2: 2015 [6]

\subsection{Statistical analysis}

The results were analyzed ANOVA and tested LSD (5\%) by software SPSS 16.0.

\section{RESULTS AND DISCUSSION}

\subsection{Egg weight loss}

After eggs membranes were created and the eggs were stored at temperatures described above for five days, they were weighted. The results of egg weight loss are represented in Figure 1 below.

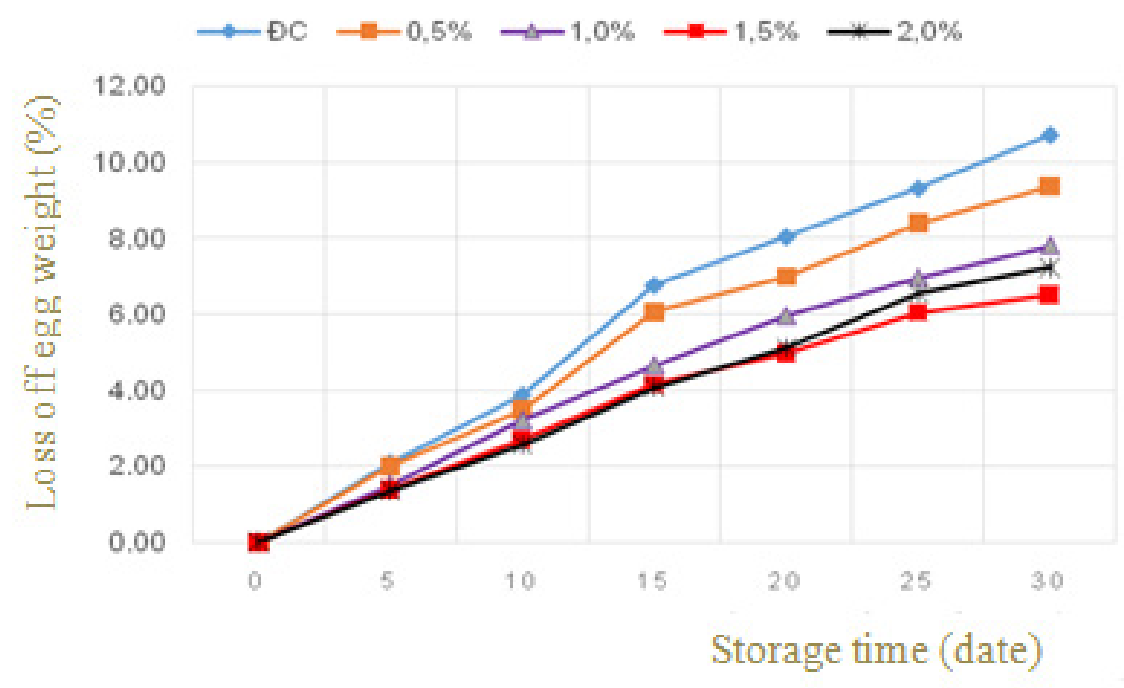

Figure 1. Loss off egg weight (\%) over storage time

The results showed that in the first ten days of storage, there was no significant difference in the weight loss between the egg with chitosan membrane and the control group (with no membrane being created, $\mathrm{p}<0.05$ ). After five days of storage, the mass of eggs in the control group decreased by $2.09 \%$. At the chitosan concentration of $2.0 \%$, the mass of eggs decreased by $1.36 \%$. 
However, from the date of the $15^{\text {th }}$ preservation onwards, weight loss remained significantly different between the preserved eggs with chitosan membrane and the control group with $\mathrm{p}$ $<0,05$. After 30 days, the mass of eggs in the control group decreased by $10.72 \%$ while eggs preserved by chitosan membrane at $1.5 \%$ concentration only decreased by $6.52 \%$. This can be explained by the fact that in the beginning period, the natural eggshells had not yet been decomposed; thus, they still had the ability of resistance to microorganisms, limiting the gas and water exchanges between the inside of eggs and external environment. However, when being stored for a long time period, the membranes inside the eggs of the control group would fade over the storage time since they did not have a chitosan membrane. This in turn led to significant weight egg loss of the control group, compared with eggs having chitosan membranes.

Nguyen Thi Lan [4] showed that after 30 days of storing chicken eggs by using chitosan membrane at $1.6 \%$ concentration, egg weight loss represented only $4.75 \%$, while the control group reached up to $8.24 \%$ [4]. In comparison with the study result of Nguyen Thi Lan [4], the egg weight loss of our research was higher. The reason is due to the difference in size between chicken and duck eggs, resulting in the difference in water loss during storage time.

\subsection{Protein content}

In addition to determining the weight loss of eggs, we also monitored the fluctuations in egg protein content by identifying soluble protein content. Results are shown in Figure 2 below.

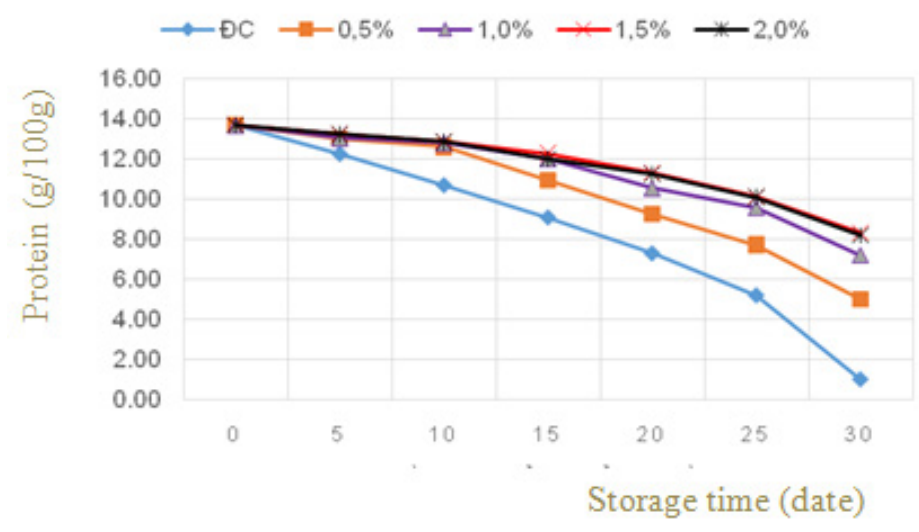

Figure 2. Changes in the protein content of eggs during the storage time

Figure 2 shows that after 30 days of storage, the protein content of the control samples significantly reduced to $1 \%$ only. With chitosan membrane-preserved egg samples, there was also a variation in soluble protein content, but to a lesser extent compared with the control samples. This result indicates that the concentration of chitosan used to make membranes also affects the content of soluble protein.

After 30 days, eggs were preserved by chitosan membrane at $0.5 \%$ concentration, and their protein content decreased from 13.7 to $5.01 \%$. At the concentrations of 1.5 and $2.0 \%$ of chitosan membrane, the soluble protein content decreased to 8.32 and $8.2 \%$ respectively, with $\mathrm{p}<0,05$. According to research results of Nguyen Thi Lan [4], after 20 days of preserving chicken eggs, their soluble protein content was reduced to $0.43 \%$. By the $30^{\text {th }}$ day, the soluble protein content in the eggs was still $9.57 \%$ at the concentrations of $1.6 \%$ of chitosan [4]. The difference between our research and Nguyen Thi Lan [4] is due to the quality of chitosan used, the size of the stomata on the surface of the eggshells, and the temperature during storage time. 


\section{3. $\mathrm{NH}_{3}$ content}

During storage, under the effect of both enzymes and microorganisms, protein and several other nutrients inside the eggs were decomposed. The level of decomposition can be evaluated through $\mathrm{NH}_{3}$ content in eggs increased during storage time.

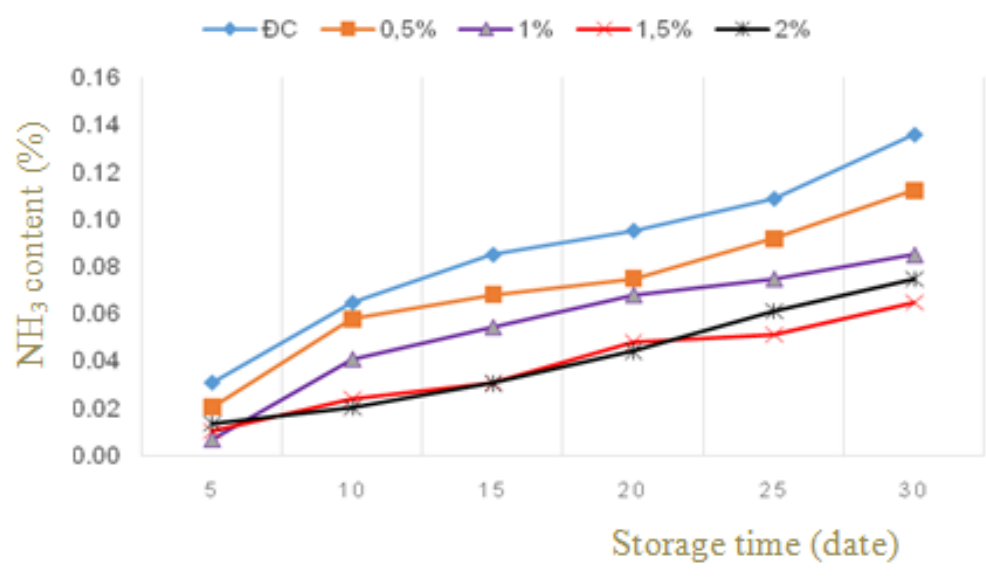

Figure 3. Changes in $\mathrm{NH}_{3}$ content during storage time

Figure 3 shows $\mathrm{NH}_{3}$ content increased gradually during storage on both samples (including the control and chitosan membrane preserved eggs). However, the samples preserved by chitosan membranes had much lower $\mathrm{NH}_{3}$ content $(0.06 \%$ with a concentration of $1.5 \%)$ compared to the control sample $0.14 \%$ with $\mathrm{p}<0,05$. This may be explained by the fact that as for the control group, gas exchange between the inside of eggs and external environment facilitated the penetration of microorganisms, leading to the increased levels of hydrolysis reaction and protein decomposition into compounds, such as $\mathrm{NH}_{3}, \mathrm{H}_{2} \mathrm{~S}$, etc. With regards to the samples preserved by chitosan membrane, this process was slower as the chitosan membranes prevent the evaporation, causing the lower level of $\mathrm{NH}_{3}$ content. When the protein content decreased, this will also lead to an increase in $\mathrm{NH}_{3}$ content.

\subsection{Ability of chitosan membrane to prevent microorganisms from penetrating the inside of the egg}

To assess the possibility of preventing the penetration of microorganisms into the egg of chitosan membrane, after 30 days of preservation, the eggs were analyzed to determine the extent of microbial infection inside the eggs through applying two indicators, including Coliforms and Salmonella spp. After 30 days of preservation, the total Coliforms were identified and the results were shown in Table 1.

Table 1. The results of the level of microbial contamination inside the egg

\begin{tabular}{cccc}
\hline Order & Chitosan membrane & $\begin{array}{c}\text { Total Coliforms } \\
(\text { MPN/100 } \mathbf{g})\end{array}$ & Salmonella spp. \\
\hline 1 & Chitosan $0.5 \%$ & 230 & Undetectable \\
2 & Chitosan $1.0 \%$ & 230 & Undetectable \\
3 & Chitosan $1.5 \%$ & 30 & Undetectable \\
4 & Chitosan $2.0 \%$ & 30 & Undetectable \\
5 & Control sample & 5.000 & Undetectable \\
\hline
\end{tabular}


- Total coliforms

The result in Table 1 above shows that for the control sample, after 30 days, the largest number of total Coliforms was 5,000 Coliforms/100 g, causing the quality of eggs to be greatly affected.

For those preserved by chitosan membrane in different concentrations, compared with the control sample, the number of Coliforms in eggs decreased sharply from 30 to 230 Coliforms/ 100 g. The strongest degree of reduction was the eggs with the chitosan concentration of 1.5 and $2.0 \%$ with the total number of Coliforms being 30 Coliforms/100g respectively.

These results showed a significant relationship $(\mathrm{p}<0.05)$ between the $\mathrm{NH}_{3}$ content and the level of microbiological contamination in eggs in the control lot and eggs preserved by chitosan membrane at concentrations from $0.5-1.0 \%$.

- Salmonella spp.

Salmonella has been recognized as a major pathogenic bacterium that causes food poisoning because it presents in many products that people use every day, such as meat, eggs, and milk, etc.

Salmonella spp. is widely distributed in the natural environment. Livestock, poultry, and human-being are often infected or become carriers of the bacteria. Typhoid (Salmonellosis) endangers public health by several strains of Salmonella related to food poisoning in humans. Pathogens are invaded mainly through food and drinking water. One of the important disease transmission is through eggs. From feces, Salmonella often infects eggshells from reproduction or litter [2].

Salmonella is one of the criteria for assessing microbial hygiene of products derived from animal origin. According to Vietnam standards (TCVN 5768-91), products derived from animal origin are not allowed to have a $25 \mathrm{~g}$ sample of Salmonella. However, our study did not identify the presence of Salmonella in the egg of the preserved samples. Thus, the chitosan membrane has the ability to prevent the entry of microorganisms which helps extend the preservation duration of fresh duck eggs.

\section{CONCLUSION}

Chitosan membranes at concentrations of $1.5 \%$ had the best positive effect to preserve fresh duck eggs at normal temperature through the following indicators: Egg weight loss after 30 days storage was $6.52 \%$; protein content after 30 days remained $8.32 \%$; $\mathrm{NH}_{3}$ content after 30 days increased at least at $0.06 \%$. The number of Coliforms after 30 days was 30 Coliforms $/ 100 \mathrm{~g}$ sample. There was no detection of the existence of Salmonella in the eggs of laboratory samples.

\section{REFERENCES}

[1]. B. T. N. Thuan, Ng. P. Tien và B. M. Duc, "Quality testing and inspection of food safety", Medical Publishing House, 1991.

[2]. C. Caner and Ö. Cansiz, "Chitosan coating minimises eggshell breakage and improves egg quality", Journal of the Science of Food and Agriculture, vol.88, pp. 56-61, 2007.

[3]. D. V. Hop, D. M. Phung, N. T. Anh and V. N. Boi, "Seafood food analysis", Agricultural Publishing House, 2006. 
[4]. N. T. Lan and H. T. Nguyen, "Study on effects of Chitosan membranes to some chemical properties of chicken eggs during storage", The Journal of Science and Technology, University of Danang, vol. 34, no. 5, pp. 81-86, 2009.

[5]. Vietnamese Standard (TCVN) 4882-2001: Microbiology-General Guide to quantitative Coliform-digital counting with the greatest probability.

[6]. Vietnamese Standard (TCVN) 10780-2:2015: Microorganisms in food and livestock food -the method of detecting, quantifying and determining the serous type of Salmonella - Part 2: Quantified by digital counting with the largest probality

[7]. S. D. Bhale, H. K. No, W. Prinyawiwatkul, K. Nadarajah, A. J. Farr and S. P. Meyers, "Chitosan coating improves the shelf life of eggs", Journal of Food Science, vol. 68, no. 7, pp. 79-84, 2003.

[8]. S. H. Kim, D. K. Youn, H. K. No, S. W. Choi and W. Prinyawiwatkul, "Effects of chitosan coating and storage position on quality and shelf life of eggs", International Journal of Food Science \& Technology, vol. 44, pp. 1351-1359, 2009.

[9]. X. D. Liu, A. Jang, D. H. Kim, B. D. Lee, M. Lee and C. Jo, "Effect of combination of chitosan coating and irradiation on physicochemical and functional properties of chicken egg during room-temperature storage", Radiation Physics and Chemistry, vol. 78, no. 7-8, pp. 589-591, 2009.

\title{
Ảnh hưởng của màng bao chitosan đển một số tính chất lý hóa của trứng vịt trong quá trình bảo quản
}

\author{
Nguyễn Minh Trí1, Chế Thị Cẩm Hà, Võ Văn Quý \\ Nguyễn Bảo Hải, Trân Thị Hảo \\ Truờng Đại học Khoa học, Đại học Huế, Thưa Thiên Huế, Việt Nam
}

Tóm tắt

Bài báo giới thiệu một số kết quả về biến đổi tính chất lý hóa của trứng vịt tươi sau khi được bảo quản bằng màng bao chitosan ở các nông độ khác nhau. Màng chitosan ở nông độ 1,5\% có tác dụng bảo quản trứng vịt tươi tốt nhất ở nhiệt độ thường. Số lượng Coliforms tổng số sau 30 ngày là 30 Coliforms $/ 100 \mathrm{~g}$ mẫu. Không phát hiện sự tôn tại của Salmonella có trong trứng của các mẫu thí nghiệm.

Từ khóa: Trúng vịt tươi, màng chitosan, chất lượng, thời gian bảo quản. 